\title{
The impact of manager's experiences in entrepreneurship evidence from Kosovo SME's
}

\author{
Esat Durguti $^{1 *}$; Enver Krasniqi ${ }^{2}$; Dea Krasniqi ${ }^{3}$ \\ 1) Faculty of Economics, University of Mitrovica, Kosovo \\ 2) Business and Management Economics, University College UBT, Kosovo \\ 3) Economic Policy and Analysis, University of Westminister, England \\ *To whom correspondence should be addressed: e-mail: esat.durguti@umib.net
}

\begin{tabular}{|l|l|l|l|l|}
\hline DOI: & Received: & Revised: & Accepted: & Published: \\
$10.22437 /$ ppd.v8i2.9447 & 02.06 .2020 & 08.06 .2020 & 09.06 .2020 & 12.06 .2020 \\
\hline
\end{tabular}

\begin{abstract}
This research accords with a detailed overview of management in general regarding SME growth development in Kosovo. So, it deals with the main factors such as the main components of management and its impact on the success and development, the techniques, and the approaches to assess the SME economic system and their development. There is no unique model which explains the managing or manager's experience and firm growth in the complexion of management theories. We have also pointed out the life cycle phases of firms that are not constructed on economic theory but have received considerable attention from managerial theories of enterprises. So, chronologically was analyzed SME development in general, given that Kosovo has a liberal trade regime characterized by simplicity and neutrality of business or SME registration. In our data analysis, we applied Cronbach's alpha for reliability analysis and linear regression. The findings of the paper show that two main topics are management experience and the growth of the sector where they operate has a significant impact. The revision opens a challenge besides wide-ranging debate taking place entrepreneurship and supervision skills in Kosovo. However, this examination has to do with evidence in Kosovo and cannot be generalized to all countries. This investigation is one of the rare researches in this field in Kosovo, which deals with the topic of SME development. This treatment approach should be used by applying dynamic approaches as well as other factors.
\end{abstract}

Keywords: Development \& Research, Management, SMEs.

JEL Classification: J50, L25, O32, C31.

\section{INTRODUCTION}

The influence of SME division on the economy has attracted the courtesy of researchers in industrialized as well as unindustrialised countries. Currently, SMEs are known to be the drivers of trade and industry through the generation of new jobs, contributions to GDP, technological innovations, and other economic and social expansion aspects. Their role, as well as importance, have been seen especially in 
unindustrialised countries, due to their basic ability to solve various economic difficulties arising after the process of alteration from a central economy to an open market economy.

The purpose of this research is to investigate the role and importance of managerial experience in the field of entrepreneurship, as well as its impact on the growth and development of SMEs in Kosovo. Kosovo is almost the last country in the region, respectively in the countries of the Western Balkans, to begin the process of transition to a market economy. In this context, SMEs can play an increasingly important role in this delayed transition trajectory, especially given that the private sector in Kosovo consists almost entirely of SMEs (there is only a certain number as enterprises large, and in recent years their structure has begun to change). For this reason, the SME sector is evident to be the main contributor to the generation of new jobs and increased income. Increasing their number also contributes to creating a competitive environment for business development.

Kosovo is a significant place for commercial progress, due to its reasonable benefits such as a young and well-qualified people, natural possessions, favorable climatic environments, new infrastructure, a fiscal policy with the lowest fiscal policy in the region, a geographical location with right of entry to the regional marketplaces, and new opportunities after the ratification of Stability Association Agreement with the European Union. Businesses in Kosovo face many managerial issues, which if neglected, will negatively affect their efficiency.

In this paper, particular importance is given in explaining and predicting management perspectives, in the given competitive market, human and material resources, and other competing capabilities that must be built on the basis of market situation and analysis. In the given competitive market, which has to be built on the basis of market situation and analysis, considering the production orientation is very necessary for Kosovar enterprises, in particular new product management, their specifics, and strategies which should be a guide for business in market economy conditions (Krasniqi, 2013). This treatment of these elements is done with the aim of advancing and managing as successfully as possible the enterprises in Kosovo, where production management should always be in line with market demand.

\section{LITERATURE REVIEW}

Nowadays, the management pursues and encourages each one in different ways. Managers run wholesale and retail businesses, hospitals and schools, art organizations, governments, and military organizations, so the question is: who are these managers and what do they work for?. These managers coordinate and control organizational resources, guide their people to the future, and assist their organizations in tracking technological and other shifts that represent the starting point for fulfilling social expectations (Krasniqi, 2013). Managerial learning streams through the speedy transfer of knowledge. This is done through sharing and interpreting information (De Long, \& Fahey, 2000). The point to which a company is dedicated to education is a planned high-quality because education is an ability, and necessitates skills and courses that must be motivated for the knowledge to be established and dispersed. In an increasing quantity of initiatives, the verdict to highlight structural education is reproduced in their authorized position that places learning first (Lackéus, 2015).

Therefore, more knowledge and expertise dispose of an entrepreneur is able to carry out appropriate actions also perform better (Frese \& Gielnik, 2014). Based on this fact, the authors Deáková, Drážovská, Grznárik, \& Kondášová (2010) have recognized the 
vital personal expertise that an entrepreneur would own is resolution, determination, innovation, and impression as well as a proactive approach. Entrepreneurs have a tendency to choose themselves as an area of the professional that receipts consistency between their specific characteristics and requirements for success.

In addition, they lean towards to manage their business through their strong and specific talents (Sidik, 2012). The greatest widespread arguments in entrepreneurship examination have conventionally revolved around micro-level factors including opportunity recognition, motivation, financing, and performance. Opportunity documentation is considered a mainstream essential issue in entrepreneurship research, given that it is an important entrepreneur capability and a source of competitive improvement (DeTienne \& Chandler., 2004). As well, opportunity identification has been linked to differences in human capital variables including education and exertion experience, advanced levels of subsequent industry or entrepreneurial experience as well as capability in management employees (Carter, Brush, Greene, Gatewood, \& Hart, 2003; Carter, Gartner, Shaver, \& Gatewood, 2003). Based on Coad (2007), the development of small companies is a particularly erratic phenomenon. Entry rates of new firms are high; however, an enormous number of these entrants can be expected to go bankrupt within a few years.

Bartelsman, Scarpetta, \& Schivardi (2005) analyze the post-entry performance of new firms in 7 OECD countries, the results disclose that about 20-40 percent of entering companies are unsuccessful inside the first two years, while only about 40-50 percent persist beyond the seventh year. Businesses must be skilled to promptly extent new knowledge to all of their entities and use it in their efforts to generate growth or prosperity (Independent Group of Scientists appointed by the Secretary-General, 2019). Speedy information transfer is also dynamic in entrepreneurial undertakings, particularly in global markets (Zahra, Ireland, \& Hitt, 2000). Structural knowledge is a precondition for invention and new undertaking establishment or commercial processes. Scholars in the field of entrepreneurship and planned organization have initiated that organizational knowledge is associated with the company's capability to renovate and constantly advance reasonable advantages (Ireland, Hitt, Camp, \& Sexton, 2005; 2001). Emerging new knowledge from organizational knowledge decreases the probability that the company's capabilities will be out-of-date. As an alternative, capabilities that are grounded on benefits continue dynamic, and they fluctuate allowing to environmental eventualities (Kathleen \& Jeffrey, 2000).

\section{METHODS}

The operational approach contains a mixture of primary as well as secondary data, through analysis of literature and observed studies. In direction to realize this examination, the practical fragment relied on gathering and dealing out data in the field, done surveys. The attention of our study remained on 500 initiatives commencing diverse regions of Kosovo. It is worth mentioning that we were a part of the Economic and Education Consulting LLC (2017) team in section development (E\&E Consulting, Kosovo).

The sample is stratified into three core segments in directive to make a distinction among production trade and services. Likewise, the sample is stratified in relationships of size which in itself remains small and medium enterprises. All firms included in the analysis are defined by the EU definition. The appointment were directed consuming the face-to-face technique through the responsible persons in several enterprise mainly 
owners or general managers.

The outcomes recommend that issues such as SME management, circumstances of the financial segment, and organization of the SMEs, corporate environment, and tactics to national markets circumstance effective Entrepreneurship and SME Strategic Development. More explicitly the research is grounded on a statistical examination of data composed from a sample developed by the E\&E Consulting, including 500 companies in Kosovo. The opinion poll grouped quantitative and qualitative data (entrepreneurship reasons, firm performance, corporate atmosphere perception, and entrepreneurship and strategic management activities information). In overall, the reaction rates of corporate managers stayed from $90-95 \%$ (from 447 - 486 respondents, nevertheless in certain specific questions, the reaction rates were lower).

To test the growth rate compared with the last year (PG), we have applied regression research by applying additional controller factors: have you been employed before $(e b s b)$, years of experience (yesb), having a BP before starting your own business (hbpsb), actually do you have a BP $(a b p)$, founder age $(f a)$, manager/owner age actually $(\mathrm{m} / \mathrm{oa})$, opinion about sector growth (osg), and opinion about profitability (ofpi).

The equation is specified as follows:

$$
\begin{gathered}
\mathrm{PG}_{c l y}=\mathrm{C}+\beta_{1} e b s b_{\mathrm{t}}+\beta_{2} \text { yes }_{\mathrm{t}}+\beta_{3} h b p s b_{\mathrm{t}}+\beta_{4} a b p_{\mathrm{t}}+\beta_{5} f a_{\mathrm{t}}+\beta_{6} m / o a_{\mathrm{t}}+\beta_{7} o s g_{\mathrm{t}} \\
+\beta_{8} o f p i_{\mathrm{t}}+\varepsilon_{\mathrm{t}}
\end{gathered}
$$

\section{RESULTS AND DISCUSSION}

The legal status of initiatives and their size also has an impact on the form of management. The study outcomes display that between SMEs in Kosovo, there is still no separation of property and management meanings. In fact, of all the businesses surveyed we can realize that $68 \%$ of them are managed by the owners, $20 \%$ by the chosen managers, $4 \%$ by the general executives, while $8 \%$ fulfilled the "other" point. Although comparable condition dominates the worldwide level, the gender gap in decision-making in SMEs is moderately evident. In the sample, $94 \%$ of managers/administrators decisionmakers in SMEs is male and only $6 \%$ corresponding with the female gender.
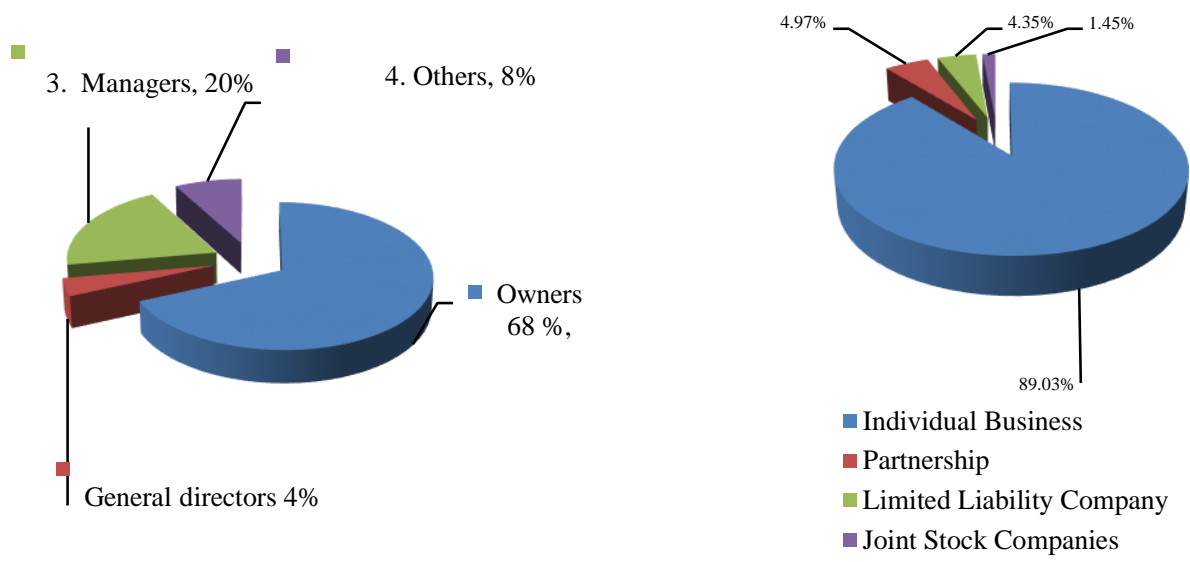

Figure 1. SME Managing and businesses by owners in \%

The Figure 1 shows that individual businesses dominate respectively with $89.03 \%$ followed by partnerships with $4.97 \%$, then LLC (Limitede Liability Company) with 4.35 $\%$ and JSC (Join Stock Companies) 1.45\%. It is worth stating that this structure 
corresponds to the structure of total documented businesses in Kosovo. Regarding Figure 2 , the relations between business founders, it is clear that family relations dominate $(65.24 \%)$ followed by professional ties $(24.39 \%)$ and joint ventures (7.32\%). This overview shows clearly that a large number of enterprises in Kosovo have family liaison and partnership. Despite this, the lack of external stakeholders in the enterprise outcomes as an obstacle to the expansion of firm's strategic management where the main focus is the growth of the company and its stability.
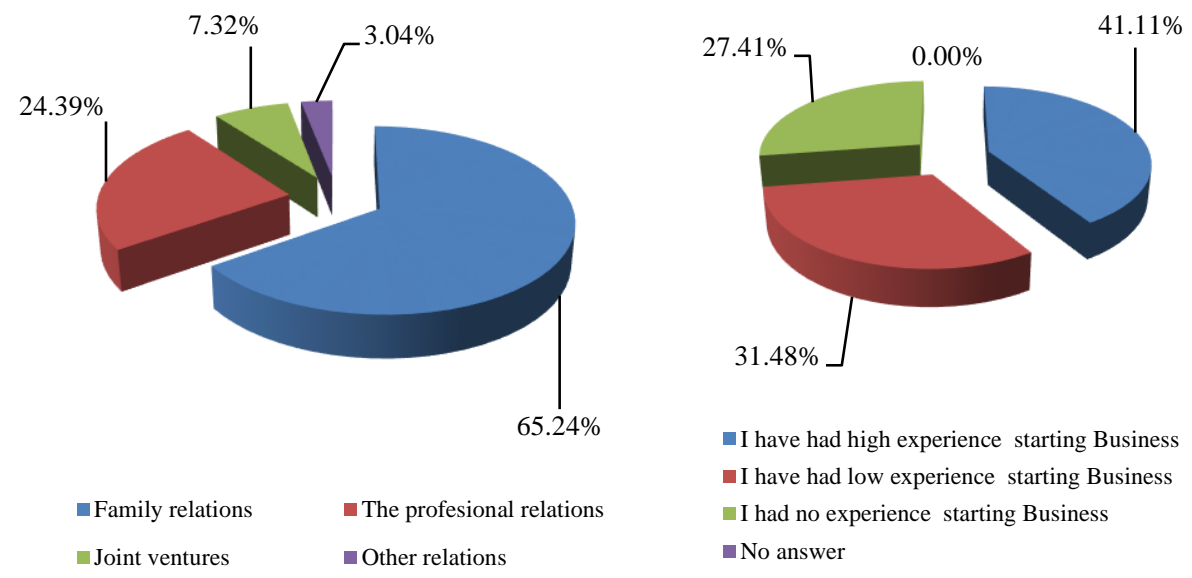

Figure. 2. Founders' relations and experience before starting business

Concerning the experience of the business founders, it shows that $41.1 \%$ had an experience, even though $31.5 \%$ said they had slight experience tracked by $27.4 \%$ who declare no experience at the moment when they make a decision to establish a business. The age group of enterprise founders is an imperative part of studying SME progress, assuming the physical, academic, professional, and experience of managing SMEs. From the table below we can see that most of the founders when they started the business were from 27 - 37 years old, while at present we have an average of 38 - 42 years old. Entrepreneur's founders at the stage when they started the business were 32.27 years old and 39.98 years old at the time of the research. In assumption, we can say that the mature and experienced individuals started to manage their business. A percentage of women as business founders were about $9.4 \%$.

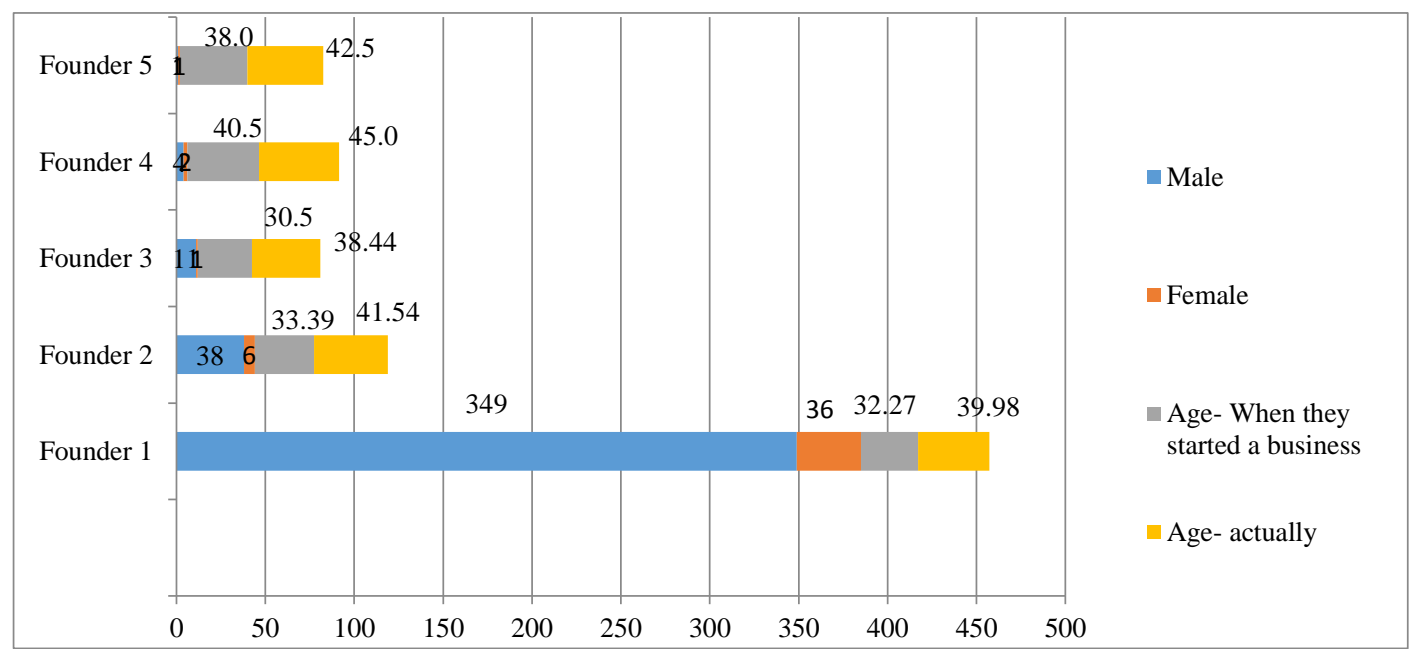

Figure. 3. The structure of SME founders by age average 
Regarding the scale of education, as shown in Figure 4, it turns out that about 56 percent of respondents have completed high school, 38 percent are faculty, 4 percent primary school, and 2 percent have completed postgraduate studies.

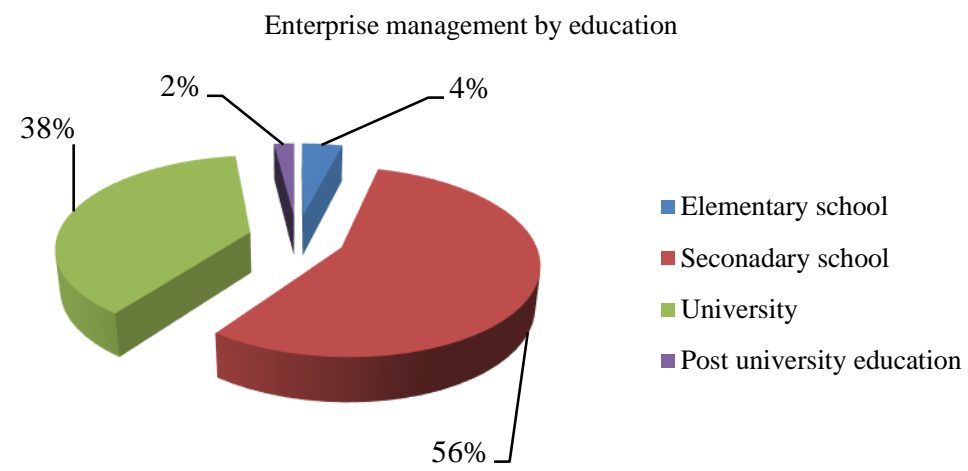

Figure. 4. Enterprise management by education

Earlier is stressed on top of this part we are going to do the examination also clarification of the outcomes obtained within the investigation. The investigation begins with a statistical outline, continued with Cronbach's Alpha analysis and multivariate regression examination to test their impact on the "Percentage growth compared to last year".

The results from research study (Table 1) stand as follows: a). The common of managers/owners have been employed before they begin their business; $b$ ). The average of years of expertise before they started a business is 7.3; c). The common started a business beyond having a BP prepared but in point of fact they recognize a value of BP idea to be prepared in advance; d). The average of founder age is 32.27 years and mangers/owners age is near 40; e) The opinion about sector growth and firm's profitability is positive and optimistic.

Table 1. Descriptive statistic

\begin{tabular}{|c|c|c|c|c|c|}
\hline & $\mathbf{N}$ & Minimum & Maximum & Mean & $\begin{array}{r}\text { Std. } \\
\text { Deviation }\end{array}$ \\
\hline $\begin{array}{l}\text { Have you been employed before you started } \\
\text { business }\end{array}$ & 479 & 1 & 2 & 1.49 & .500 \\
\hline Years of experience before starting a business & 280 & 0 & 40 & 7.30 & 6.874 \\
\hline Having a BP before starting a business & 494 & 1 & 2 & 1.75 & .432 \\
\hline Actually do you have a BP & 492 & 1 & 2 & 1.68 & .465 \\
\hline Founder age & 239 & 16 & 69 & 32.27 & 9.202 \\
\hline The manager/owner age actually & 308 & 22 & 78 & 39.98 & 10.768 \\
\hline $\begin{array}{l}\text { What is your opinion about sector growth } \\
\text { where you operate }\end{array}$ & 494 & 1 & 3 & 1.80 & .740 \\
\hline $\begin{array}{l}\text { What is your opinion about firm's profitability } \\
\text { in your industry }\end{array}$ & 474 & 1 & 4 & 2.37 & .798 \\
\hline Valid N (list wise) & 148 & & & & \\
\hline
\end{tabular}

Starting the results produced by the descriptive facts to the question of have, you were employed before opening your corporate, as of 479 questionnaires resulted in a middling value of 1.49 , however, what was their work experience before they started their business was with an average value of 7.30. Reliability analysis data in our study stand close to a perfect steadiness, but based on many revisions the constant of (Cronbach's Alpha) above 0.60 is considered adequate. However, in our situation, this 
coefficient is 0.678 .

To evaluate the level of influence inside the chosen indicators we tend to execute the multifactor analysis. During this occasion, the dependent factors are chosen "Percentage growing compared with the previous year". From the applied examination the outcomes show that from the eight controlling factors, only three of them devise a major impact on "Percentage growing related with the previous year". The multifactor analysis of business barriers on the percentage of SME growth compared with the previous year was significant by years of experience beforehand starting a business (Sign $0.017)$, "Knowledge about sector growth where they operate" - with importance 0.015 and Have you been engaged before you started the business - with importance 0.021 (Table 2).

Table 2. Model summary

\begin{tabular}{cccccc}
\hline Model & $\mathrm{R}$ & $\mathrm{R}^{2}$ & $\mathrm{R}^{2}$ Adjusted & $\begin{array}{c}\text { Std. Error of } \\
\text { the Estimate }\end{array}$ & $\begin{array}{c}\text { Durbin- } \\
\text { Watson }\end{array}$ \\
\hline & $.627 \mathrm{a}$ & .584 & .527 & .0312506 & 1.721 \\
\hline
\end{tabular}

a. Dependent Variable: Percentage growth compared with last year

The following table shows the summary of the linear regression model with the following data: $\mathrm{R}, \mathrm{R}^{2}$, and $\mathrm{R}^{2}$ adjusted, as well as the estimated standard error. The results obtained from the model data show that the dependent variable has a strong correlation with the explanatory variables at the level of .627 , respectively 62.7 percent. While $\mathrm{R}^{2}$ in our analysis is .584 , which shows that 58.4 percent of the dependent variable is explained by the independent variables. The adjusted $\mathrm{R}^{2}$ is equal to .527 , which indicates that 52.7 percent of the variation of the dependent variable is explained by the variation of the independent variables. The Durbin-Watson test was used to analyze the data on whether the serial correlation is available. The result obtained in our case is 1.721 , which is within the specified interval and that the data have no correlation or auto-correlation between the residual values.

Table 3. The linear data regression - coefficients

\begin{tabular}{|c|c|c|c|c|c|}
\hline Model & $\begin{array}{c}\text { Unst. } \\
\text { B }\end{array}$ & $\begin{array}{r}\text { Coeff. } \\
\text { Std. } \\
\text { Error }\end{array}$ & $\begin{array}{r}\text { St. Coeff. } \\
\text { Beta }\end{array}$ & $\mathrm{t}$ & Sig. \\
\hline (Constant) & 32.480 & 16.818 & & 1.931 & .006 \\
\hline $\begin{array}{l}\text { Have you been employed before you started } \\
\text { business }\end{array}$ & 9.867 & 4.808 & .092 & 1.012 & .021 \\
\hline $\begin{array}{l}\text { Years of experience before starting a business - } \\
\text { yesb }\end{array}$ & 11.1982 & .405 & .235 & 2.428 & .017 \\
\hline Having a BP before starting a business & 3.615 & 6.235 & .067 & .580 & .563 \\
\hline Actually do you have a BP & 3.488 & 5.766 & .068 & .605 & .546 \\
\hline Founder age & .004 & .415 & .002 & .010 & .992 \\
\hline The manager/owner age actually & -.064 & .353 & -.030 & -.182 & .856 \\
\hline $\begin{array}{l}\text { What is your opinion about sector growth where } \\
\text { you operate }\end{array}$ & -15.094 & 3.117 & -.147 & -1.63 & .015 \\
\hline $\begin{array}{l}\text { What is your opinion about firm's profitability in } \\
\text { your industry }\end{array}$ & -1.102 & 3.367 & -.030 & -.327 & .744 \\
\hline a. Dependent Variable: Percentage growth compa & vith last & & & & \\
\hline
\end{tabular}

The controlling variable "yesb" is importantly associated with percentage growth paralleled to last year, as the p-value is 0.017 . The study is in relation to the studies conducted by the authors (Frese and Gielnik, 2014), where according to them it turns out 
that the added awareness and experience an entrepreneur consumes, he has the talent to perform unconventional. The confirmed result gives us indications that work expertise in the past takes dominant importance in the growing and extension of corporate activities, who is confirmed even during the carrying out of the questionnaire has resulted in an average of 1.5 years have had work experience before to start corporate activities.

The highest influence constant on a firm's growth was observed in question what is your opinion about sector growth where you operate, with a contrary constant of -15.094 and one with high-reliability sign $[\mathrm{P}=0.015]$. The last variable that has an important positive result is "were you employed by any company before you started your private", with an importance level of 95.0 percent. And centered on this, it turns out that expertise or previous work knowledge has an influence on increasing management activities.

Our result is in line with the authors Deáková, Drážovská, Grznárik, \& Kondášová (2010). Results for indicators having a BP before starting a business and currently having a BP, have proven to be insignificant. The results of the study are in inverse cohesion with the studies conducted by the authors (Morris \& Sexton, 1996; Zahra \& Garvis, 2000), where they argue that these indicators have unsustainable positive correlations. This result is reasonable by analyzing the specific circumstances of the business environment in Kosovo. Other indicators that have proved insignificant are founder age and actually owner/manager's age. The results are correlated with the study conducted by the author Honjo (2015), who argues that individual age is not found to be a significant predictor of entrepreneurship choice and thus it shows the irrelevancy of individual age to business start-ups.

\section{CONCLUSIONS AND RECOMMENDATIONS}

\section{Conclusions}

The private segment in Kosovo contains micro, small, medium and large enterprises. SME constitutes $99 \%$ of all companies in Kosovo, indicating a massive potential in the generation of new jobs and economic development. The first step is to encourage as many SMEs to enter the formal sector regarding regulatory procedures for businesses, whereas the second step that came from our research is improving the "Nonadequate level of employee skills" and "Manager/owner skills".

A study utilized advanced technique to spot as well as to measure the influence of managing, firm, and environmental elements on firm growth. Cronbach's Alpha was utilized for a reliability scale for indicators and also the multivariate analysis model was designed to examine the impact of managing issues, firm, strategy, and the institutional situation on firm growths'. Econometric marks exhibition is that the expertise and division inside which these companies operate have a significant impact on firm growth. The examination results stand almost reliable with the expectations set, besides the investigation of the regression model gives us evidence that proves that the experience and possession of adequate knowledge in the field in which the business operates are substantial, and have impacts on increasing / decreasing SME's. This revision paves the way for new discussions in the field of entrepreneurship and research as well as encourages the application of approaches or techniques with statistical dynamics, as well as applying other issues that may have an impact on SME's.

\section{Recommendations}

Improving organizational change management and the need for SMEs to be managed by executive managers or management teams is another recommendation, 
having in mind that about $70 \%$ of SMEs are managed by owners. Increasing awareness about starting a business by analyzing opportunities to realize a business idea and starting a business with a prepared business plan. Increasing awareness about the importance of business knowledge and experiences. Increasing awareness of entrepreneurs for start-ups to have a prepared Business Plan which can be organized by the Ministry of Trade and Industry and other donors i.e. EU and USAID by financing training and other informative methods

Penetration in the regional and international markets with the quality of services especially in different IT services because of the high percentage of youngsters who have multi-language (especially in the English, German, Italian languages) and advanced skills in the IT sector.

\section{REFERENCES}

Bartelsman, E., Scarpetta, S. \& Schivardi, F. (2005). Comparative Analysis of Firm Demographics and Survival: Evidence from Micro-Level Sources in OECD Countries (June 2005). Industrial and Corporate Change, 14(3), 365-391, 2005. Available at SSRN: https://ssrn.com/abstract=914655

Carter, N., Brush, C., Greene, P., Gatewood, E., \& Hart, M. (2003), Women entrepreneurs who break through to equity financing: the influence of human, social and financial capital, Venture Capital Journal, 5(1), 1-28. https://doi.org/10.1080/1369106032000082586

Carter, N.M., Gartner, W.B., Shaver, K.G. \& Gatewood, E.J (2003). The career reasons of nascent entrepreneurs. Journal of Business Venturing, 18(1), 13-39 doi:10.1016/S0883-9026(02)00078-2

Coad, A. (2007). Firm growth: a survey. Documents de travail du Centre d'Economie de la Sorbonne, Université Panthéon-Sorbonne (Paris 1), Centre d'Economie de la Sorbonne, https://EconPapers.repec.org/RePEc:mse:cesdoc:r07024

De Long, D. \& Fahey, L. (2000). Diagnosing cultural barriers to knowledge management. The Academy of Management Executive, 14(4), 113-127. https://doi.org/10.5465/ame.2000.3979820

Deáková, K., Drážovská, K., Grznárik, D., \& Kondášová, I. (2010). Entrepreneurship. Bratislava: SOPK.

DeTienne, D.R. \& Chandler, G.N. (2004). Opportunity identification and its role in the entrepreneurial classroom: a pedagogical approach and empirical test. Academy of Management Learning \& Education. 3(3), 242-257. https://doi.org/10.5465/AMLE.2004.14242103

Economic and Education Consulting LLC. (2017). SME Research Report. Prishtinë.

Frese, M. \& Gielnik, M. M. (2014). The Psychology of Entrepreneurship. Annual Review of Organizational Psychology and Organizational Behavior, 1(1), 413 - 438. https://doi.org/10.1146/annurev-orgpsych-031413-091326

Independent Group of Scientists appointed by the Secretary-General, Global Sustainable Development Report. (2019). The Future is Now - Science for Achieving Sustainable Development. New York: United Nations

Honjo, Y. (2015). Why are entrepreneurship levels so low in Japan? Japan and the World Economy, 36, 88-101.

Ireland, D.R., Hitt, M.A., Camp, M.S., \& Sexton, D.L. (2001). Strategic entrepreneurship: entrepreneurial strategies for wealth creation. Strategic Management Journal, 22(67), 479-491. DOI: 10.1002/smj.196 
Kathleen, M.E. \& Jeffrey, A.M.. (2000). Dynamic Capabilities: What Are They. Strategic Management Journal. 21(10-11), 1105-1121 https://doi.org/10.1002/10970266(200010/11)21:10/11<1105::AID-SMJ133>3.0.CO;2-E

Krasniqi, E. (2013). Integrimi i aktiviteteve të Ndërmarrësisë dhe Menaxhimit strategjik

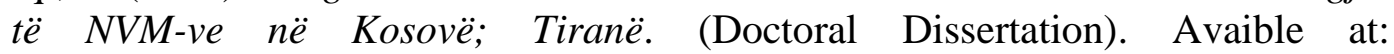
http://www.doktoratura.unitir.edu.al/wp-content/uploads/2014/01/DoktoraturaEnver-H.-Krasniqi-Fakulteti-Ekonomik-Departamenti-i-Manaxhimit.pdf.

Lackéus, M. (2015). Entrepreneurship in Education: What, why, when, how. In Entrepreneurship360 Background Paper, Paris, France: OECD

Morris, M.H., \& Sexton, D.L. 1996. The concept of entrepreneurial intensity: Implications for firm performance. Journal of Business Research, 36(1), 5-13.

Ireland, R.D., Hitt, M.A., Camp, S.M. \& Sexton, D.L. (2005). Integrating Entrepreneurship and Strategic Management Actions to Create Firm Wealth. Academy of Management, 15(1), 49-63. https://www.jstor.org/stable/4165710

Sidik, G.I. (2012). Conceptual framework of factors affecting SME development: Mediating factors on the relationship of entrepreneur traits and SME performance. Procedia Economics and Finance, 4, 373-383. DOI 10.1016/S22125671(12)00351-6

Zahra, S.A., Ireland, R.D. \& Hitt, M.A. (2000). International expansion by new venture firms: International diversity, mode of market entry, technological learning, and performance. The Academy of Management Journal, 43(5), 925-950 https://doi.org/10.5465/1556420

Zahra, S., \& Garvis, D. 2000. International corporate entrepreneurship and firm performance: The moderating effect of international environmental hostility. Journal of Business Venturing, 15(5), 469-492.

(C) 2020 by the authors. Licensee JPPD, Indonesia. This article is an open access article distributed under the terms and conditions of the Creative Commons Attribution (CC BY) license (http://creativecommons.org/licenses/by/4.0/). 